\title{
Automatic TIG welding of austenitic stainless steels in nitrogen and nitrogen-based gas mixtures ${ }^{(\bullet)}$
}

\author{
B. Zorc*
}

\begin{abstract}
The paper treats studies of TIG gas-shielded arc welding using pure nitrogen, $\mathrm{N}_{2}+5-20 \%$ Ar gas mixtures and $\mathrm{N}_{2}$ $+2-10 \% \mathrm{H}_{2}$ gas mixtures. A weld root shielding was provided by nitrogen gas. Welding in $\mathrm{N}_{2}$ requires by $40 \%$ lower welding current than welding in argon. The study showed that porosity was an issue due to overalloying of $\mathrm{N}_{2}$ in the weld pool; it can, however, be avoided with adequate welding parameters, particularly sufficiently high welding speed and controlled low heat input. The microstructure of all-weld metal is fully austenitic $(\gamma)$. Hydrogen reduces nitrogen solubility in the weld pool and produces an austenitic-ferritic $(\gamma+\delta)$ microstructure. Titanium increases nitrogen solubility in the weld pool and strongly reacts with nitrogen. Consequently, there is a high fraction of TiN inclusions in the weld metal.
\end{abstract}

\section{Soldadura TIG automática de acero inoxidable austenita en una atmósfera de protección de nitrógeno y mezclas de gas a base de nitrógeno}

\begin{abstract}
Resumen
Hemos efectuado las investigaciones de la soldadura TIG en nitrógeno puro, las mezclas de gas $\mathrm{N}_{2}+5$ hasta un $20 \%$ Ar, así como también $\mathrm{N}_{2}+2$ hasta un $10 \% \mathrm{H}_{2}$. Para la protección se utilizó nitrógeno. Para la soldadura se necesitan aproximadamente un $40 \%$ menos de corriente de soldadura, comparado con la soldadura de argón. La investigación ha mostrado que la porosidad es un problema de absorción excesiva de la fundición con nitrógeno y que es posible suprimir la porosidad mediante parámetros adecuados de soldadura, sobre todo con una suficiente velocidad de soldadura y, con ella, una pequeña emisión controlada de calor. El hidrógeno reduce la solubilidad del nitrógeno en la fundición y acciona la segregación de ferrita. El titanio aumenta la solubilidad del nitrógeno en la fundición y reacciona fuertemente con el nitrógeno, de tal modo que en la soldadura hay una gran parte de inclusiones TiN.
\end{abstract}

Palabras clave

Soldadura TIG; Acero inoxidable austenita; Nitrógeno; Hidrógeno.

\section{INTRODUCTION}

TIG welding is the most widely used process for joining austenitic stainless steel sheets. Shielding gases used with this process are argon and various gas mixtures of argon with hydrogen (up to $10 \%$ of $\mathrm{H}_{2}$ ), and argon with helium, which is more rarely. Root shielding is provided by argon, nitrogen and gas mixtures of argon with hydrogen or of nitrogen with hydrogen (up to $20 \%$ of $\mathrm{H}_{2}$ ).

Control of nitrogen content in a weld and a nitrogen influence on metallurgical, mechanical and corrosion properties were topics of numerous studies on welding of austenitic stainless steels ${ }^{[1-11,14,19-25]}$, duplex stainless steels ${ }^{[6,7,12,19}$ and 20], and nickel alloys ${ }^{[13]}$. Nitrogen is introduced into a weld with a filler material or a shielding gas. The majority of studies were carried out with gas mixtures of argon with $1 \%-10 \%$ of nitrogen. Studies treating a higher nitrogen content in argon, e.g. argon + more than $20 \%$ of nitrogen ${ }^{[3 \text { and } 11]}$, are scarcer. A reason for this may be findings that even small additions of nitrogen to argon $\left(>1.4 \%\right.$ of $\mathrm{N}_{2}{ }^{[11]},>2 \%$ of $\left.\mathrm{N}_{2}{ }^{[12]}\right)$ may produce weld porosity. The following nitrogen contents in argon, i.e. $>3.5 \%,>4 \%[21$ and 25$]>5.6 \%$, $>6.3 \%^{[11]},>5 \%{ }^{[6]},>15 \%{ }^{[2]},>25 \%{ }^{[3]}$, were also found to cause porosity in welds, which depended on the type of steel. For example, a gas mixture of argon

(•) Trabajo recibido el día 26 de Noviembre de 2009 y aceptado en su forma final el día 17 de Junio de 2010.

*Welding institute, Ptujska 19, 1000 Ljubljana (Slovenia). 
with $25 \%$ of nitrogen was found to produce strong porosity in welds at steel 1.4301 (AISI 304), but not in welds at steel 1.4845 (AISI 310S) ${ }^{[3]}$. This indicates that the presence of nitride-forming elements, e.g. chromium, titanium, niobium, tantalum, vanadium, increases nitrogen solubility in molten steel. Steel with a higher content of these elements, separately or in combination, is capable of dissolving a larger amount of nitrogen, which is shown by a comparison of welds at steels 1.4301 and 1.4845 . To say in other words, these elements increase a critical content of nitrogen in the weld that produces porosity. A similar effect is noticed with surface-active elements, e.g. sulphur in steel, an addition of oxygen to argon ${ }^{[11}$ and 14$]$, or a higher nitrogen content in a parent metal ${ }^{[11]}$.

In austenitic and duplex stainless steels nitrogen is an alloying element. In superaustenitic stainless steels it can reach up to $0.6 \mathrm{~m} \%$ [15 and 21]. It is a very strong austenite stabilizer, it is cheap and, consequently, an excellent substitute for nickel ${ }^{[3,11,19}$ and 23]. Nitrogen hardens steel in two ways, i.e. with interstitial alloying of solid solution and with precipitation hardening by forming tiny nitrides ${ }^{[2,3 \text { and } 24]}$. In this way yield strength and tensile strength in the range from cryogenic to high temperatures are improved ${ }^{[1-5,11,20,23}$ and 24]. At cryogenic temperatures, toughness decreases only slightly ${ }^{[11]}$. Stronger hardening of a weld, particularly with multipass welds, in comparison with a parent metal, which can be attributed to a higher portion of precipitation hardening, was found ${ }^{[3]}$. It was found that yield strength in welds at steel 1.4401 (AISI 316) increases by $62 \mathrm{~N} / \mathrm{mm}^{2}$ with each $0.01 \mathrm{~m} \%$ of nitrogen in a weld ${ }^{[2]}$. Nitrogen hinders the formation of integranular, precipitated carbides and thus prevents the generation of intercrystalline corrosion ${ }^{[1,2,11 \text { and } 15]}$. It also hinders the formation of other unfavourable intermetallic phases, such as $\sigma$ phase ${ }^{[15]}$. Nitrogen improves resistance to pitting corrosion and to crevice

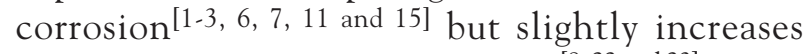
susceptibility to hot cracking of welds ${ }^{[8,22}$ and 23$]$ and to stress corrosion ${ }^{[1 \text { and } 2]}$. Nitrogen also decreases susceptibility to cold cracking of welds in duplex stainless steels by control of ferrite content ${ }^{[19]}$.

Nitrogen content in a weld depends on welding

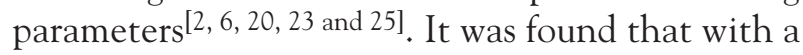
constant current an increase of voltage by $10 \mathrm{~V}$ increases the nitrogen content in the weld by $0.1 \%$. Similarly a decrease in current with a constant voltage also increases nitrogen content in the weld ${ }^{[2]}$. A content of dissolved nitrogen along the weld length is different if the proportion of nitrogen in the shielding gas exceed the suggested values ${ }^{[12]}$.

The smallest is at the beginning and greatest at the end of the weld ${ }^{[12]}$. Nitrogen content in the weld is a sum of nitrogen absorbed in the interaction between a gas and a molten metal and of nitrogen in a parent metal ${ }^{[2]}$. The weld nitrogen concentration increases with an increase in the shielding gas nitrogen content ${ }^{[11,14,20,22,23 \text { and } 25]}$ at low nitrogen partial pressures $^{[11 \text { and } 14]}$. At higher partial pressures, nitrogen absorption was balanced by $\mathrm{N}_{2}$ evolution ${ }^{[11}$ and 14] .

A welding arc in nitrogen has, similarly as in

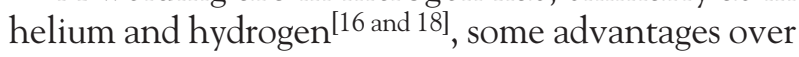
argon. With the same current, voltage is twice as high as with argon ${ }^{[16-18]}$.

The arc temperature is higher ${ }^{[16,17}$ and 23$]$ and concentrated in a narrower range ${ }^{[17]}$. This means that energy input per volume unit is higher and, in turn, permits higher welding speeds, the same as with helium and hydrogen. A weakness of nitrogen in welding shows in arc instability due to reactions with a tungsten electrode ${ }^{[3,13,16 \text { and } 25]}$. The latter will inflate and peel off due to an increased volume due to the formation of tungsten nitride. Compared to tungsten the latter shows poorer electric conductivity; therefore, the recommended nitrogen content is below $3 \%$ [13].

Because of the above-mentioned weaknesses there are obviously no detailed studies on TIG welding of austenitic stainless alloys in nitrogen. But the favourable influences on austenitic alloys, favourable features of the arc, and a low price of nitrogen present a challenge for studying welding in nitrogen, which would be the cheapest TIG process variant.

\section{EXPERIMENTAL PROCEDURE}

Investigations were carried out at three austenitic stainless steels, i.e. 1.4301 (AISI 304), 1.4401 (AISI 316), and 1.4541 (AISI 321), having a thickness of $0.7 \mathrm{~mm}$. Thicknesses of $0.6 \mathrm{~mm}, 0.8 \mathrm{~mm}, 1.0 \mathrm{~mm}$, $1.2 \mathrm{~mm}, 1.5 \mathrm{~mm}$, and $2.0 \mathrm{~mm}$ apply to 1.4301 steel specimens. Chemical compositions of the steels having the thickness of $0.7 \mathrm{~mm}$ are given in table I.

The welding procedure used was automatic TIG welding on a copper backing, a welding source having a high-frequency ignition and the highest welding current being $202 \mathrm{~A}$. A gas nozzle had a diameter of $10 \mathrm{~mm}$ and a tungsten electrode WT 20 that of $2.4 \mathrm{~mm}$. The tungsten electrode stick-out was $5 \mathrm{~mm}$ and the length of the electric arc ranged between 1.0 and $1.5 \mathrm{~mm}$. The welding current used was chosen in order to obtain, with the chosen welding current and the same plate thicknesses, the same weld widths in all shielding gases.

This provided an equal heat input in welding in all the shielding gases concerned. Instability of the electric arc (which dances to the right and to the left with reference to the direction of welding and most 
AUTOMATIC TIG WELDING OF AUSTENITIC STAINLESS STEELS IN NITROGEN AND NITROGEN-BASED GAS MIXTURES SOLDADURA TIG AUTOMÁTICA DE ACERO INOXIDABLE AUSTENITA EN UNA ATMÓSFERA DE PROTECCIÓN DE NITRÓGENO Y MEZCLAS DE GAS A BASE DE NITRÓGENO

Table I. Chemical compositions of the austenitic stainless steels studied; thickness: $0.7 \mathrm{~mm}$ (wt.\%)

Tabla I. Composición química en la investigación de los aceros inoxidables austenitautilizados de $0,7 \mathrm{~mm}$ de grosor (de peso \%)

\begin{tabular}{ccccccccccc}
\hline Steel & $\mathbf{C}$ & $\mathbf{S i}$ & $\mathbf{M n}$ & $\mathbf{P}$ & $\mathbf{S}$ & $\mathbf{C r}$ & $\mathbf{M o}$ & $\mathbf{N i}$ & $\mathbf{T i}$ & $\mathbf{N}$ \\
\hline 1.4301 & 0.05 & 0.55 & 1.70 & 0.027 & 0.002 & 18.00 & 0.135 & 8.71 & 0.0054 & 0.0313 \\
1.4401 & 0.032 & 0.45 & 1.73 & 0.037 & 0.002 & 16.85 & 2.02 & 11.40 & 0.0464 & 0.0116 \\
1.4541 & 0.027 & 0.54 & 1.62 & 0.028 & 0.002 & 17.31 & 0.30 & 9.84 & 0.1295 & 0.0087 \\
\hline
\end{tabular}

probably contributes to weld defects) was eliminated by grinding the tungsten electrode before each weld was made. The length of respective test pieces prepared was $500 \mathrm{~mm}$ (square butt weld without a filler material) and $1000 \mathrm{~mm}$ (remelting of the entire plate). Two different welding speeds, i.e. $58 \mathrm{~cm} / \mathrm{min}$ and $80 \mathrm{~cm} / \mathrm{min}$, were used.

Testing included the following shielding gases: Ar, $\mathrm{N}_{2}, \mathrm{~N}_{2}+2$ of $\mathrm{H}_{2}, \mathrm{~N}_{2}+5 \%$ of $\mathrm{H}_{2}, \mathrm{~N}_{2}+7 \%$ of $\mathrm{H}_{2}$, $\mathrm{N}_{2}+10 \%$ of $\mathrm{H}_{2}, \mathrm{~N}_{2}+5 \%$ of $\mathrm{Ar}, \mathrm{N}_{2}+10 \%$ of Ar, $\mathrm{N}_{2}+15 \%$ of $\mathrm{Ar}, \mathrm{N}_{2}+20 \%$ of Ar. All the gases were prepared in gas cylinders. The root was shielded by nitrogen. Shielding-gas flow rates used were $7 \mathrm{l} / \mathrm{min}$, $9 \mathrm{l} / \mathrm{min}$ and $15 \mathrm{l} / \mathrm{min}$ and for root shielding $4 \mathrm{l} / \mathrm{min}$.

The welds produced were examined using radiographic testing to assess porosity and cracks. Nitrogen content in the parent metal and welds was determined with a classical method and a method of atomic vacuum emission spectroscopy. For the classical method, thin wires were cut only from allweld metal. Results of nitrogen measurements in welds with the spectroscopic method were not decisive since the surface examined was larger than the weld width. The $\delta$ ferrite content in the parent metal and welds was measured with a device based on magnetic induction (Fischer, Feritscope MP30). The welds were metallographically examined (grinding: $\mathrm{SiC}$ wet papers up to no. 4000 ; polishing: diamond paste with particle size $1.0 \mathrm{~m} \mu$; etching: glyceregia). The entire analysis was made for a thickness of $0.7 \mathrm{~mm}$.

For other thicknesses only partial analyses (RT, $\delta$ ferrite measurement, influence of a shielding gas on welding current) were made.

\section{RESULTS AND DISCUSSION}

Austenitic stainless steels 1.4301, 1.4401 and 1.4541 can be quality welded with the welding parameters chosen in all the shielding gases concerned. The tests conducted showed that welding of the same plate thickness with the same welding speed the welding current required is by almost $40 \%$ lower $\left[\mathrm{I}_{\mathrm{N} 2}=\right.$ $\left.(0.55 \div 0.6) \cdot \mathrm{I}_{\mathrm{Ar}}\right]$ with nitrogen and nitrogen-based mixtures (additions of up to $20 \%$ of argon or up to $10 \%$ hydrogen) than with argon. The parameters are given in figure 1.

With reference to the shielding gases used, the welds were visually acceptable. There were no surface defects. The root side of the welds of titaniumstabilized steel showed golden yellow colour with nitrogen due to titanium nitride formed. Radiographic testing showed that the welds in general did not contain pores, but if they did, these were only isolated pores and primarily in square butt welds. This means that the findings stated in technical literature that few percentages of nitrogen in argon may result in porous welds hold only for the alloys and welding parameters (max. welding speeds were $25 \mathrm{~cm} / \mathrm{min}$ ) used. The welding speeds used in our tests $(58 \mathrm{~cm} / \mathrm{min}$ and $80 \mathrm{~cm} / \mathrm{min}$ ) do not permit the weld pool to take up an overcritical content of nitrogen even in case of pure nitrogen, which would result in nitrogen bubbling in the solidification process. In the welds produced and tested the nitrogen content never exceeded $0.191 \%$.

Average nitrogen contents measured in the welds at the $0.7 \mathrm{~mm}$ thick plate are given in figure 2 . The results indicate that with the increasing hydrogen content in nitrogen the nitrogen content in the weld decreases. In comparison with welding in pure nitrogen, the nitrogen content in the weld is on the average by $0.0543 \%$ lower when $5 \%$ of hydrogen is added. When gas mixtures with an addition of argon are used, nitrogen content in a weld of the same steel is lower than in case of use of nitrogen alone and higher than in case of use of the mixtures with hydrogen. They are, however, still high enough that the addition of $20 \%$ of argon to nitrogen provides a pure austenitic microstructure of the weld at the steels studied. Figure 3 shows a dendritic $(\gamma+\delta)$ weld microstructure obtained in nitrogen $+10 \%$ of hidrogen with steels 1.4301 and 1.4541 and also a 


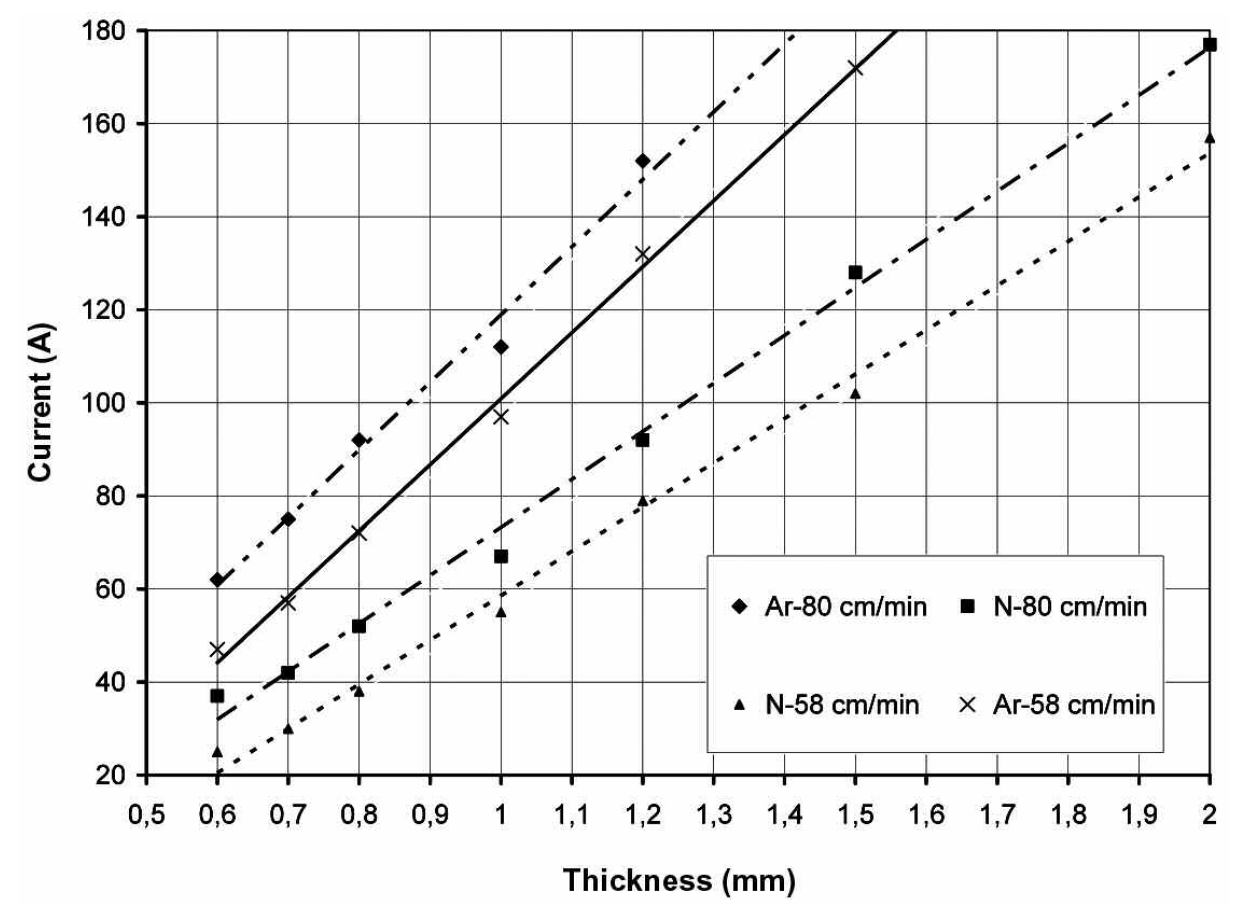

Figure 1. Welding currents required for welding with full penetration of welded thicknesses ( $\mathrm{N}$ - nitrogen and nitrogen-based mixtures).

Figura 1. Corrientes de soldadura necesarias para la soldadura de los espesores soldables ( $N$ - nitrógeno y mezclas de gases a base de nitrógeno).

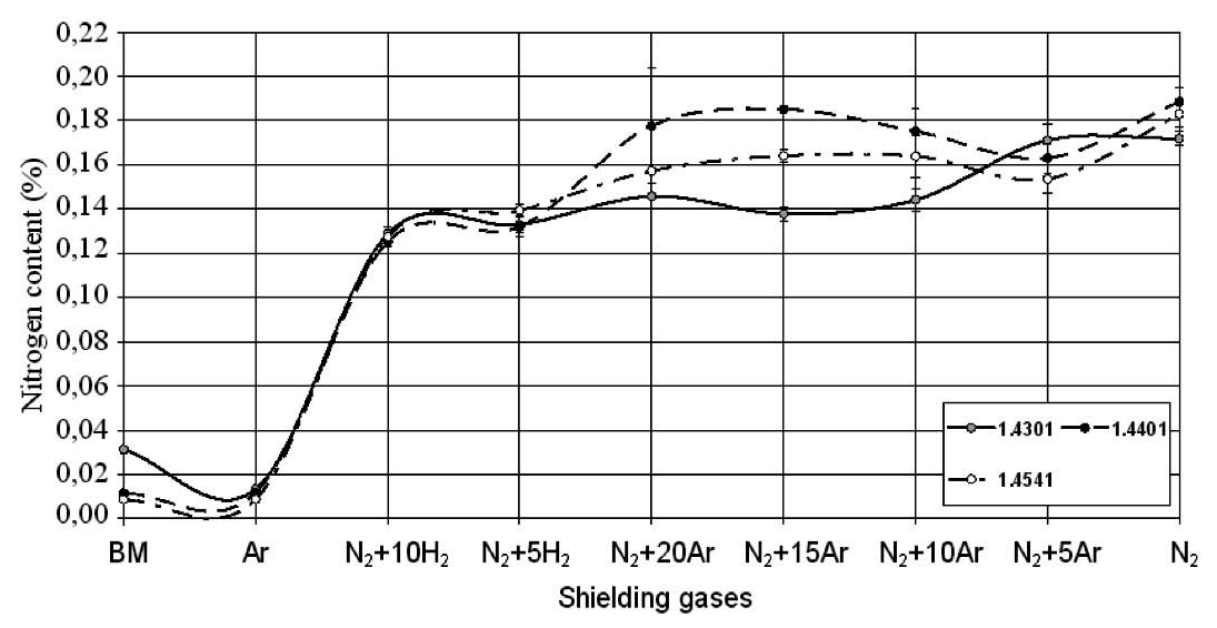

Figure 2. Nitrogen content measured in joints on $0.7 \mathrm{~mm}$ steel welded in different shielding gases (wt \%).

Figura 2. Contenido medido de nitrógeno en las soldaduras de acero de 0,7 $\mathrm{mm}$ de grosorsoldados en diferentes gases de protección (de peso \%).

dendritic-austenitic $(\gamma)$ weld microstructure obtained in nitrogen with steels 1.4401 and 1.4541 . Weld microstructures obtained in the gas mixtures with an addition of $20 \%$ of argon are the same as in nitrogen.
In steel 1.4541 there is a large quantity of titanium nitrides in the weld (Figs. 3 b), 4 d) and f) - gray and dark points)), which is much larger than in case of welding in argon. This proves that in the formation 

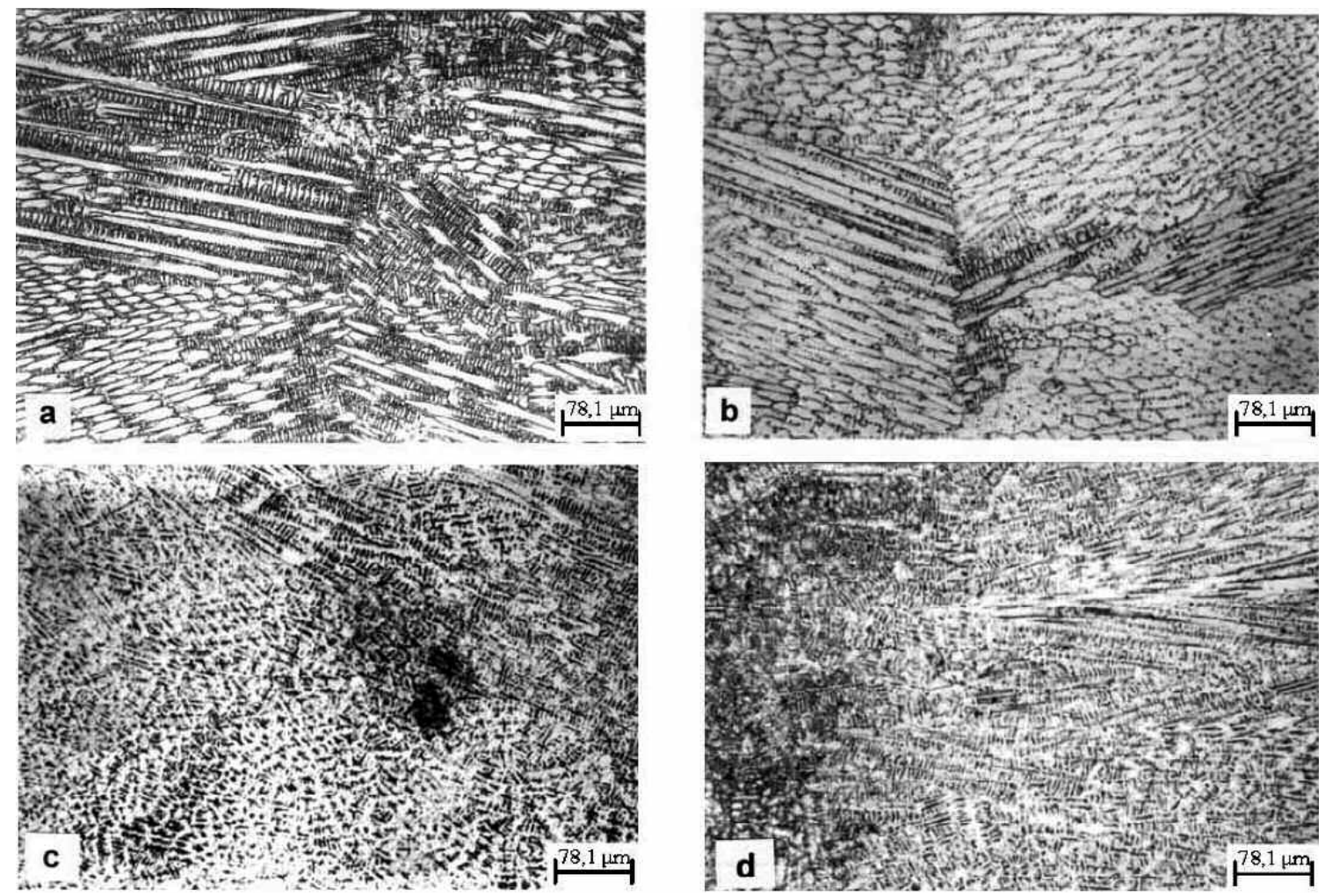

Figure 3. Dendritic weld microstructure $(a, b: \gamma ; c, d: \gamma+\delta)$ shielding gas: $N_{2}$, a) steel 1.4401, b) steel $1.4541 ; \mathrm{N}_{2}+10 \% \mathrm{H}_{2} ;$ c) steel $1.4301, \mathrm{~d}$ ) steel 1.4541.

Figura 3. Microestructura dendrítica de la soldadura $(a, b: \gamma ; c, d: \gamma+\delta)$ gas de protección: $N_{2}$, a) acero $\left.1.4401, b\right)$ acero $\left.1.4541 ; N_{2}+10 \% H_{2}, c\right)$ acero $\left.1.4301, d\right)$ acero 1.4541.

of nitrides in the weld, titanium dissolved in steel in the austenitic solid solution takes part as well.

Welding in nitrogen with an addition of hydrogen produces an austenitic-ferritic microstructure $(\gamma+$ $\delta)$. The larger the quantity of hydrogen in nitrogen is, the larger the quantity of $\delta$ ferrite in a weld (Figs. 4 e), f), g) and h)) - sceletal type dark phase)). The microstructure is becoming like the one formed in welding in argon. An increased $\delta$ ferrite content in the weld results in a smaller content of nitride inclusions, which additionally proves the influence of hydrogen on reduced solubility of nitrogen in the weld pool. Solidification of fully austenitic composition gives columnar coarse microstructure, while the $(\gamma+\delta)$ microstructure are finer (Fig. 3). The nitrides exert no essential influence on the size of austenitic grains (Figs. 3 a) and b)). It seems that the cooling rate is so high and nitrides can not essential affected on grain size.

The microstructure is in accordance with the nitrogen content in the weld, which is confirmed by $\delta$ ferrite measurements (Fig. 5). The highest amount of $\delta$ ferrite was measured in the welds obtained in welding in argon and the smallest one in the welds obtained in welding in nitrogen and the mixtures with the addition of up to $20 \%$ of argon. The welds with the addition of hydrogen show less $\delta$ ferrite than the ones with argon but more than the ones in nitrogen and the mixtures with argon. This was confirmed also with the other plate thicknesses (Fig. 6). The highest $\delta$ ferrite contents were found in the welds at steel 1.4401 made in argon and the nitrogen mixtures with hydrogen. All of the three steels studied were semi-austenitic, which means that in an inert atmosphere their weld pool solidifies via the $\delta$ ferrite zone or two-phase zone $(\gamma+\delta)$. Steel 1.4401 alloyed with molybdenum, which is a strong ferritizer; therefore, the welds produced in argon and with the addition of hydrogen, show a somewhat larger quantity of $\delta$ ferrite.

The all-weld metals produced in nitrogen and in the mixtures with the addition of $20 \%$ of argon show an austenitic microstructure (Figs. 3 a), b), 4 c) and d)). The relevant heat-affected zone (HAZ) contains $\delta$ ferrite, which is a characteristic of all the shielding gases and steels used in the study. For steel 1.4301 this is shown in figure 7 . The $\delta$ ferrite measured in the welds produced in nitrogen and in 

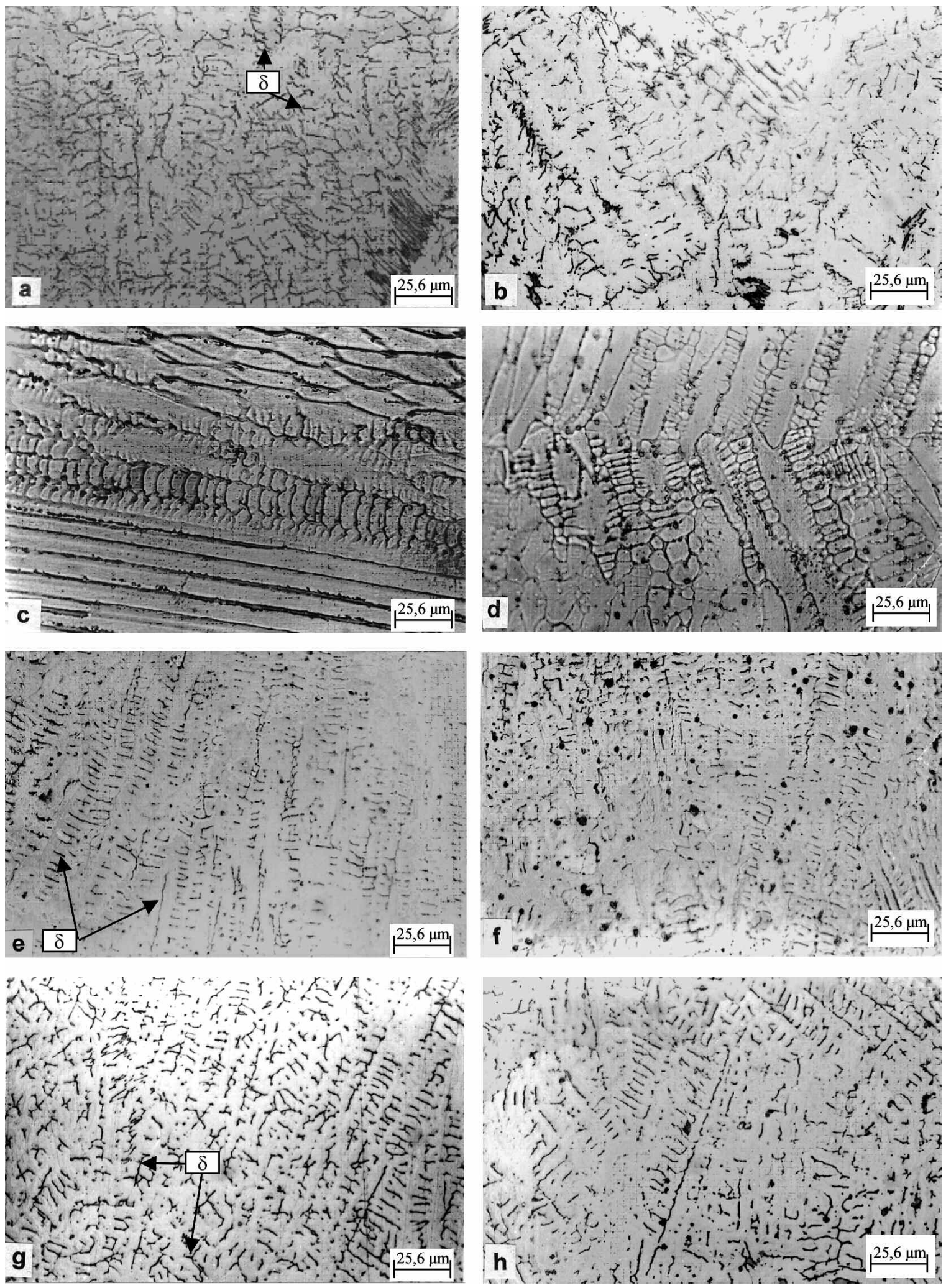

Figure 4. Effect of hydrogen in nitrogen on weld microstructure, steel $1.4301 \mathrm{a}), \mathrm{c}), \mathrm{e}), \mathrm{g}$ ), steel 1.4541 b), d) ,f) ,h), shielding gases: Ar a), b), $\mathrm{N}_{2} \mathrm{c}$ ), d), $\mathrm{N}_{2}+5 \% \mathrm{H}_{2}(\mathrm{e}, \mathrm{f}), \mathrm{N}_{2}+10 \% \mathrm{H}_{2}$ g) ,h).

Figura 4. Influencia del hidrógeno en el nitrógeno en la microestructura de la soldadura, acero 1.4301 a), c), e), g), acero 1.4541 b), d), f), h); gas de protección: $A r, b), N_{2}(c, d)$, $\left.\left.\mathrm{N}_{2}+5 \% \mathrm{H}_{2}(e, f), \mathrm{N}_{2}+10 \% \mathrm{H}_{2} g\right), h\right)$. 


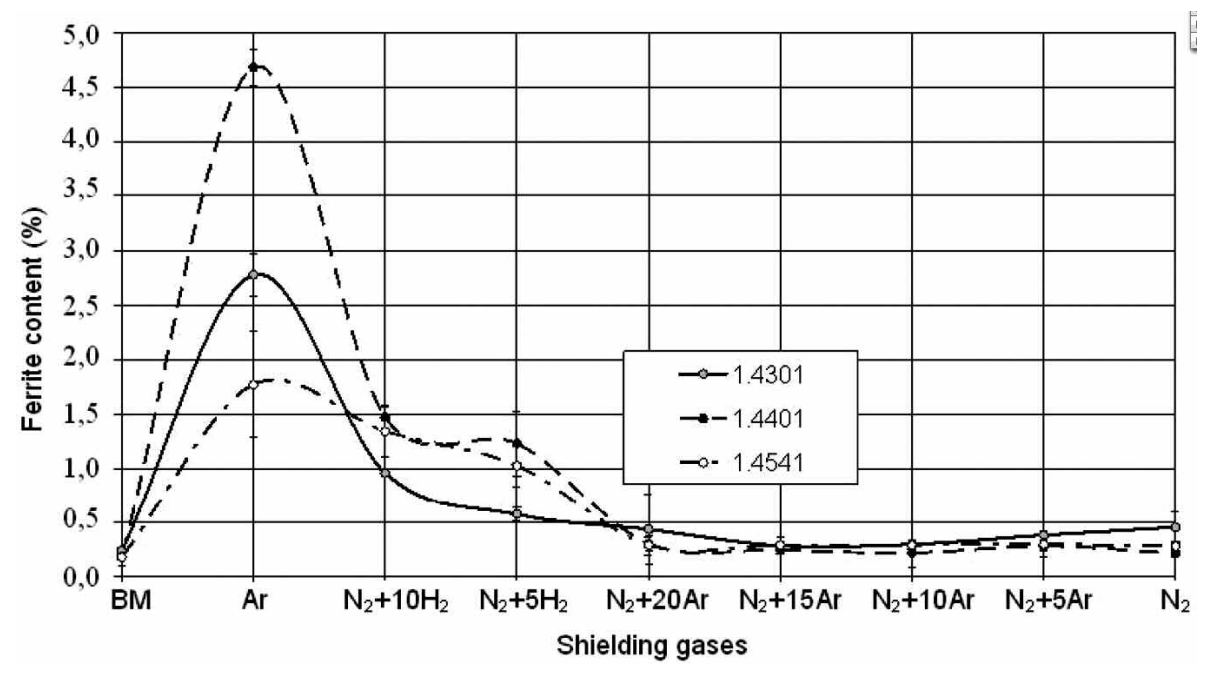

Figure 5. $\delta$ ferrite content (\%) in joints on $0.7 \mathrm{~mm}$ steel welded with a welding speed of $80 \mathrm{~cm} / \mathrm{min}$ in different shielding gases.

Figura 5. Contenido $\delta$ de ferrita en las soldaduras con velocidad de 80 $\mathrm{cm} / \mathrm{min}$ en diferentes gases de protección, acero de $0,7 \mathrm{~mm}$ de grosor.

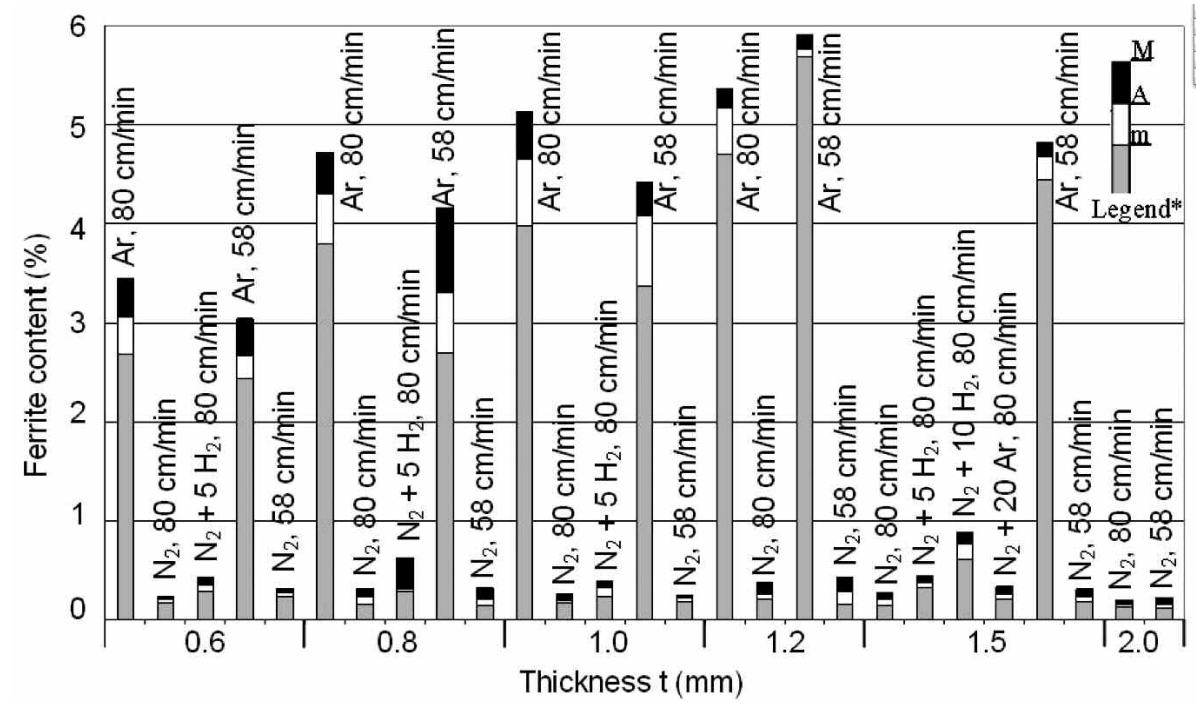

Figure 6. $\delta$ ferrite content (\%) in joints on steel 1.4301 welded in different shielding gases (average of five measurements, legend*: $M$ - maximum, A - average, $m$ - minimum) .

Figura 6. Contenido $\delta$ de ferrita (\%)en las soldaduras de acero 1.4301, soldados en diferentes gases de protección (promedio de cinco mediciones, * Leyenda: máxima, media, mínima).

the gas mixtures with the addition of up to $20 \%$ argon is found only in the HAZ, whereas $\delta$ ferrite of the welds produced in argon and the mixtures with an addition of $2-10 \%$ of hydrogen this is a sum of ferrite in the all-weld metal and HAZ. Rapid cooling of the weld prevents nitrogen diffusion into the HAZ and, consequently, the nitrogen influence on reduced $\delta$ ferrite in the HAZ. Rapid cooling also prevents the transformation of $\delta$ ferrite into austenite, which would otherwise be expected on the basis of the phase diagram.

From a comparison of the microstructure and nitrogen in the weld metal it can be inferred that a critical dissolved-nitrogen content for the formation 

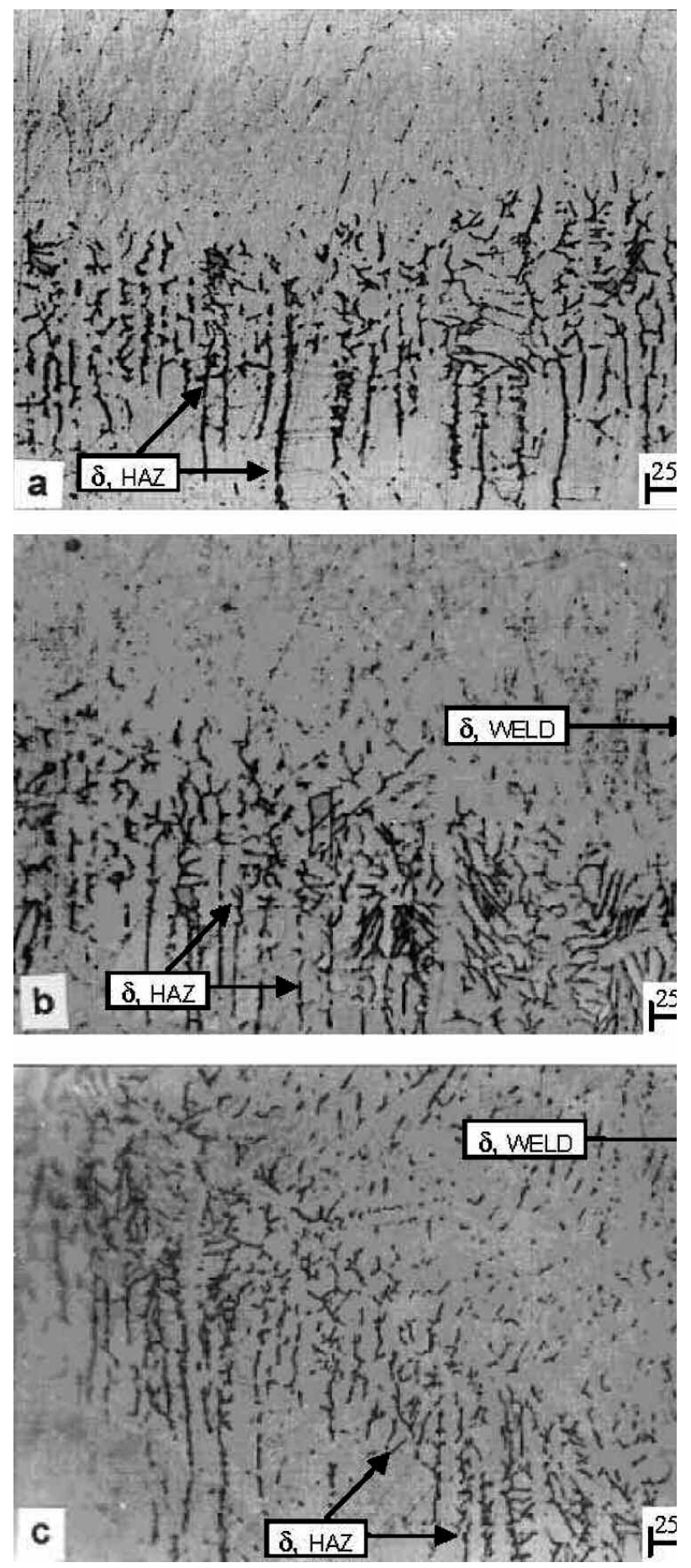

Figure 7. $\delta$ ferrite in the heat-affected zone (HAZ). steel: 1.4301; shielding gas: $\mathrm{N}_{2}(\mathrm{a}), \mathrm{N}_{2}+5$ $\% \mathrm{H}_{2}$ (b), $\mathrm{N}_{2}+10 \% \mathrm{H}_{2}$ (c).

Figura 7. $\delta$ ferrita en una zona de influencia de calor acero: 1.4301; gas de protección: $\mathrm{N}_{2}$ a), $\mathrm{N}_{2}+5 \% \mathrm{H}_{2}$, b), $\left.\mathrm{N}_{2}+10 \% \mathrm{H}_{2}, c\right)$.

of a pure austenitic microstructure of the weld metal with steels 1.4301 and 1.4401 amounted to around $0.135 \%$, and with steel 1.4541 to around $0.142 \%$.
In a reference ${ }^{[2]}$ this limit is set at $0.105 \%$ for steel 1.4306 (304L).

As regards different material thicknesses and welding parameters (ref. ${ }^{[2]}$ : thickness of $12.5 \mathrm{~mm}$, welding current of $175 \mathrm{~A}$, welding speed of 10 $\mathrm{cm} / \mathrm{min}$ ) the results are mutually comparable. Because of rapid cooling of the welds in our study, more nitrogen was required to stabilize the austenitic microstructure. For austenite stabilization, more nitrogen is required in titanium-stabilized steel than in non-stabilized steel, a reason being that a certain fraction of dissolved nitrogen combines into $\mathrm{TiN}$ inclusions whereas austenite is stabilized only by the nitrogen dissolved in the metal.

\section{CONCLUSIONS}

- Automatic TIG welding of austenitic stainless steel sheets (non-stabilized steels 1.4301,1.4401 and titanium-stabilized steel 1.4541) in nitrogen and nitrogen-based gas mixtures with an addition of up to $20 \%$ of argon or $10 \%$ of hydrogen, using no filler material but suitable welding parameters, it is possible to produce non-porous welds.

- High welding speeds, i.e. ranging between 58 and $80 \mathrm{~cm} / \mathrm{min}$, prevent excessive pick-up of nitrogen by the weld pool and the formation of $\mathrm{N}_{2}$ bubbles.

- Nitrogen is a strong stabilizer of the austenitic microstructure. The gas mixtures with the addition of $20 \%$ of argon also produce austenitic microstructure of the all-weld metal whereas the addition of as little as $2 \%$ of hydrogen to nitrogen produces the occurrence of small amounts of $\delta$ ferrite. This means that hydrogen reduces nitrogen solubility in the weld pool.

- Due to rapid cooling of the weld the level of nitrogen diffused into the HAZ is too low to affect its microstructure. A proof is $\delta$ ferrite in the HAZ of which the content is similar as in the weld produced in argon.

- For stabilization of austenite in a weld of titanium-stabilized steel 1.4541 in comparison with steels 1.4301 and 1.4401 , a larger quantity of nitrogen dissolved in the weld pool is required since a part of nitrogen combines with titanium to form TiN inclusions.

- Nitrogen increases the amount of TiN inclusions in the titanium-stabilized steel weld in comparison with the welds made in argon. This proves that in the formation of nitrides in the weld, titanium dissolved in steel in the austenitic solid solution takes part as well.

- Welding in nitrogen and nitrogen base gas mixture in comparison with argon requires less 
energy since the welding currents required to weld the same plate thicknesses with the same welding speeds amount to $(0.55 \div 0.6) \cdot \mathrm{I}_{\mathrm{Ar}}$.

\section{REFERENCES}

[1] W.A.Baeslack, W.F. Savage and D.J. Duquette, Weld. J. 58 (1997) 83-90.

[2] R.K.Okagawa, R.D. Dixon and L.Olson, Weld. J. 62 (1983) 204-209.

[3] T. Ogawa, K. Suzuki and T. Zaizen, Weld. J. 63 (1984) 213-223.

[4] T. Ogawa and T. Koseki, Weld. J. 67 (1988) 8-17.

[5] T. Ogawa, T. Koseki, S. Ohkita and H. Nakajima. Weld. J. 69 (1990) 205-212.

[6] R. Petersen and O. Runnerstam, Svetsaren, 47 (1993) 11-15.

[7] N. Stenbacka, Svetsen, special issue 3 (1995) 46-49.

[8] V. Shankar, T.P.S. Gill, S.L. Mannan and S. Sundaresan, Weld. J. 77 (1998) 103-201.

[9] G. Lothongkum, P. Chaumbai and P. Bhandhubanyong, J. Mat. Proc. Tech. 89-90 (1999) 410-414.

[10] G. Lothongkum, E. Viyanit and P. Bhandhubanyong, J. Mat. Proc. Tech. 110 (2001) 233-238.

[11] M. Du Toit and P.C. Pistorius, Weld. J.82 (2003) 219-224.
[12] R. Wiktorowicz and J. Crouch, Weld. J. \& Met. Fabr. October (1994) 379-382.

[13] M. Zinke and A Hübner, Praktiker 9 (2002) 308-312.

[14] M. Du Toit and P.C. Pistorius, Weld. J. 82 (2003) 231-237.

[15] S. Lamb and J. E. Bringas, Ed., Casti Handbook Of Stainless Steels \& Nickel Alloys. Ed. Casti Publishing Inc. Edmunton, Alberta, Canada, (2000) 246-248.

[16] T. Lyman, E. A. Durand and P. M. Unterweiser, Ed. Metals Handbook, Welding and brazing, 8th edition, American Society for Metals, Metals Park, Ohio 6 (1971) pp. 122-123.

[17] J. Haidar, A.J.D. Farmer and J. Phys. D: Appl. Phys. 26 (1993) 1.224-1.229.

[18] D. Böhme, DVS-Verlag, Düsseldorf, DVS Berichte Bd. 127 (1989) pp. 78-91.

[19] B. Bonnefois, F. Dupoiron and P. Soulignac, Weld. Res. C. B. 374 (1992) 65-71.

[20] S. Hertzman and S. Wessman, Mat. Sci. F., 318320 (1999) 579-590.

[21] M. Harzenmoser, C. Rennhard, M. Hereth and M. Diener, Mat. Sci. F., 318-320 (1999) 591-596.

[22] O. Kamiya and Y. Kikuchi, Mat. Sci. F. 318320 (1999) 609-614.

[23] H.Y. Huang, Mat. \& Des. 30 (2009) 2.4042.409 .

[24] C. Efstathiou and H. Sehitoglu, Mat. Sci. \& Eng., A, 506 (2009) 174-179.

[25] L. Zhao, Z.L. Tian and Y. Peng, Sci. and Tech. of Weld. \& Join. 14 (2009) 87-92. 